\title{
STRUKTUR KOMUNITAS PLANKTON DI PERAIRAN PULAU BANGKA KABUPATEN MINAHASA UTARA
}

\author{
(Plankton Community Structure at Bangka Island Water \\ North Minahasa Regency)
}

\author{
Muh. Shabir Usman ${ }^{1^{\star}}$, Janny D. Kusen ${ }^{1}$, Joice R.T.S.L Rimper ${ }^{1}$ \\ ${ }^{1}$ Program Studi IImu Kelautan, Fakultas Perikanan dan IImu Kelautan, Universitas Sam \\ Ratulangi, Manado \\ "e-mail : shabirusman1983@gmail.com
}

This research was conducted at Bangka Island waters, East Likupang District, North Minahasa Ragency. Plankton samples were collected using plankton net at 6 (six) points at 2 (two) different depths such as the surface area and $10 \mathrm{~m}$ depth. In order to collect samples, the plankton net were horizontally and vertically towed in February 2012, then fixed with $4 \%$ formline before identified at Marine Biology laboratory, Faculty of Fisheries and Marine Sciences, Sam Ratulangi University, Manado. The results of this research has been showed that the plankton from both depths were consists of 6 genera from 5 orders, each of them were order Gonyaulacales, Bacillariales, Pennales and Oscillatoriales have one genera respectively, and only Order Centrales have 2 genera. All of plankton species that found on each study site were holoplankton type, whereas diatom species were mostly found. The important value index that found at the surface area was from Pseudoenotis doliolus species within highest value as high as 86.017, while Skeletoma sp. Species as highest value at $10 \mathrm{~m}$ depth as 88,627 . The diversity index of plankton at Bangka Island waters has been showed at moderate level indicated that the environment tend to be unstabled, therefor plankton dominance showed low level mean no plankton species dominance yet on that area.

Keywords : plankton, Bangka Island, community structure.

Penelitian ini dilakukan di perairan Pulau Bangka, Kecamatan Likupang Timur Kabupaten Minahasa Utara. Pengambilan sampel plankton dilakukan pada 6 (enam) titik dengan 2 (dua) kedalaman berbeda yaitu pada lapisan permukaan dan kedalaman 10 meter yang dilakukan pada bulan Februari 2012. Pengambilan sampel menggunakan plankton net dengan penarikan secara horizontal dan vertikal. Proses pengawetan plankton menggunakan formalin $4 \%$, selanjutnya proses identifikasi dilakukan di Laboratorium Biologi Kelautan Fakultas Perikanan dan IImu Kelautan Universitas Sam Ratulangi Manado. Hasil penelitian menunjukkan bahwa plankton yang ditemukan di perairan Pulau Bangka pada dua titik kedalaman terdiri dari 6 genera dari 5 ordo yaitu ordo Gonyaulacales 1 genus, ordo Bacillariales 1 genus, ordo Centrales 2 genus, dan ordo Oscillatoriales 1 genus, Penales 1 genus. Jenis plankton yang ditemukan pada setiap stasiun menunjukkan bahwa hampir semua daur hidupnya adalah holoplankton, plankton dari jenis diatom adalah yang banyak ditemukan. Indeks nilai penting yang diperoleh berdasarkan hasil analisis pada lapisan permukaan adalah Pseudoenotis doliolus dengan nilai tertinggi yaitu 86,017 dan jenis Skeletonema sp, memiliki nilai penting tertinggi di kedalaman 10 meter dengan nilai 88,627. Keanekaragaman plankton di perairan Pulau Bangka menunjukkan suatu bentuk keanekaragaman yang sedang. Dominansi plankton di perairan Pulau Bangka menunjukkan suatu bentuk dominansi rendah.

Kata Kunci : plankton, Pulau Bangka, struktur komunitas. 


\section{PENDAHULUAN}

Plankton merupakan biota yang teramat beranekaragam dan terpadat di laut. Banyak biota laut yang daur hidupnya menempuh lebih dari satu cara hidup, pada saat mereka menjadi larva atau juvenil, mereka hidup sebagai plankton (Romimohtarto dan Juwana 1999). Plankton mempunyai peranan yang sangat penting di dalam ekosistem bahari, dapat dikatakan sebagai pembuka kehidupan di planet bumi ini, karena dengan sifatnya yang autotrof mampu merubah hara anorganik menjadi bahan organik dan penghasil oksigen yang sangat mutlak diperlukan bagi kehidupan makhluk yang lebih tinggi tingkatannya (Isnansetyo dan Kurniastuty 1995).

Studi tentang keberadaan plankton dan struktur komunitas di Perairan Sulawesi Utara, khususnya di perairan Pulau Bangka belum adanya penelitian tentang struktur komunitas plankton, sehingga penelitian ini dianggap penting untuk mendapatkan informasi ilmiah.
Laut merupakan sebuah ekosistem besar yang di dalamnya terdapat interaksi antara faktor biotik dan abiotik. Interaksi yang terjadi bersifat dinamis dan saling mempengaruhi. Lingkungan menyediakan tempat hidup bagi organisme-organisme yang menempatinya, sebaliknya makhluk hidup dapat mengembalikan energi yang dimanfaatkannya ke dalam lingkungan. Suatu daur energi memberikan contoh nyata akan keberadaan interaksi tersebut.

\section{METODE PENELITIAN}

\section{a. Lokasi dan Waktu Penelitian}

Lokasi penelitian yaitu di perairan Pulau Bangka, Kecamatan Likupang Timur Kabupaten Minahasa Utara (Gambar 1). Pengambilan sampel plankton dilakukan di 6 (enam) titik dengan 2 (dua) kedalaman berbeda yaitu pada lapisan permukaan dan kedalaman 10 meter yang dilakukan pada bulan Februari 2012, selanjutnya diidentifikasi di

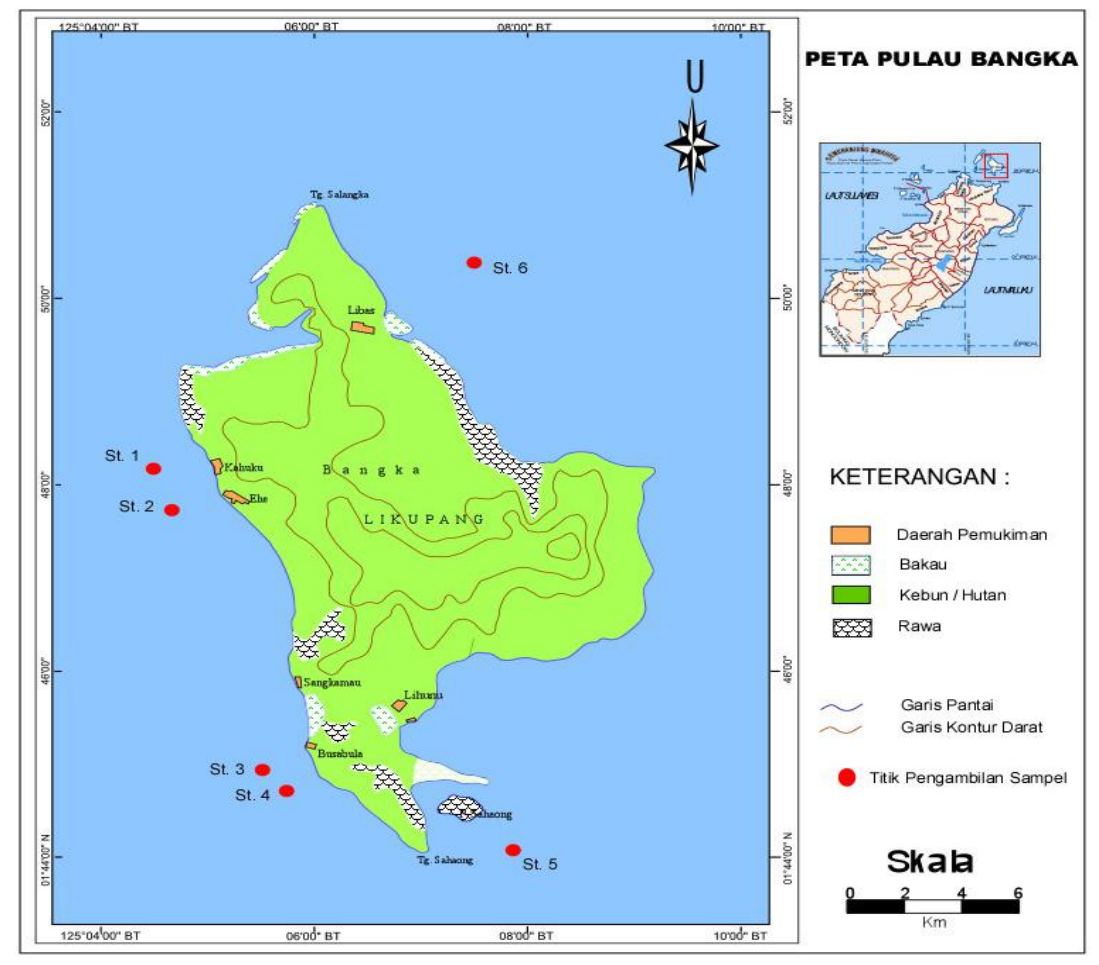

Gambar 1. Lokasi Penelitian 
Laboratorium Biologi Kelautan Fakultas Perikanan dan IImu Kelautan Universitas Sam Ratulangi Manado.

\section{b. Prosedur Kerja dan Penanganan Sampel}

Pengambilan sampel plankton di lapisan permukaan air dilakukan secara horizontal, plankton net diletakkan di permukaan air kemudian ditarik dengan bantuan perahu menuju ke titik lain. Pengambilan sampel seiring dengan kecepatan perahu secara perlahan $( \pm 2$ knot), plankton net ditarik untuk jarak dan waktu tertentu ( \pm 5-8 menit), kemudian air yang tersaring dalam botol (bucket) dimasukan ke dalam botol sampel yang telah diberi label agar terhindar dari kekeliruan untuk diawetkan.

Pengambilan sampel plankton pada kedalaman 10 meter dilakukan dengan menggunakan jaring cekik (closing net). Ketika kapal berhenti, GPS diaktifkan untuk mengetahui posisi, setelah itu plankton net diturunkan sampai pada kedalaman $10 \mathrm{~m}$ dengan pemberat dibawahnya, kemudian tali yang terdapat di sebelah kanan ditarik sehingga jaring tertutup (tercekik) hingga sampel yang diperoleh tidak tercampur dengan sampel yang lain. Selanjutnya plankton net ditarik keatas dengan kecepatan konstan, kemudian air yang tersaring dalam botol (bucket) dimasukkan dalam botol yang telah berisi formalin $4 \%$ untuk diawetkan

\section{c. Analisa Data}

\section{Kepadatan Plankton}

Kepadatan spesies plankton dianalisis dengan menggunakan rumus kepadatan (Cox, 1967):

Kepadatan spesies $=$

Jumlah individu spesies

Luas wilayahcontoh $\left(\mathrm{m}^{2}\right)$

Kepadatan spesies $A$

Kepadatan Relatif (\%) $=\longrightarrow$ X100

Kepadatan spesies total

\section{Indeks Keanekaragaman Spesies}

Indeks keanekaragaman spesies adalah ukuran kekayaan komunitas dilihat dari jumlah spesies dalam suatu kawasan, berikut jumlah individu dalam tiap spesies. Indeks keanekaragaman spesies dianalisis dengan menggunakan formula Shannon-Wiener dalam Ludwig dan Reynolds (1988).

$H^{\prime}=-\sum(n i / N \ln n i / N)$

Dimana :

$\mathrm{H}^{\prime}$ : Indeks keanekaragaman spesies

ni :Jumlah individu dalam spesies ke-i

$\mathrm{N}$ : Jumlah total individu

Keterangan :

$H^{\prime}<1$ : Keanekaragaman rendah dan keadaan komunitas rendah

$1<H^{\prime}<3$ : Keanekaragaman sedang dan keadaan komunitas sedang

$\mathrm{H}^{\prime}>3$ : Keanekaragaman tinggi dan keadaan komunitas tinggi

\section{Indeks Dominansi Spesies}

Dominansi spesies adalah penyebaran jumlah individu tidak sama dan ada kecenderungan suatu spesies mendominasi. Untuk mengetahui indeks dominan dalam suatu habitat digunakan rumus di bawah ini (Odum 1994 dalam Lombok 2003).

$$
\mathrm{C}=\sum(\mathrm{ni} / \mathrm{N})^{2}
$$

Dimana

C : Indeks dominan spesies

ni : Jumlah individu setiap spesies i

$\mathrm{N}$ : Jumlah total individu seluruh spesies

Keterangan :

$\mathrm{C}<0,50 \quad$ : Dominasi rendah

$0,50<\mathrm{C}<0,75$ : Dominasi sedang

$0,75<\mathrm{C}<1 \quad$ : Dominasi tinggi

\section{Indeks Dominansi Relatif (\%)}

Dominansi spesies $A$

Dominansi Relatif $(\%)=\longrightarrow 100$

Dominansi total spesies 


\section{FrekuensiJenis Plankton}

Untuk mengetahui frekuensi jenis plankton dianalisis dengan menggunakan formula menurut Bengen (2000):

$\mathrm{Fi}=\mathrm{Pi} / \sum \mathrm{P}$

Dimana :

$\mathrm{Fi}$ : Frekuensi Jenis

$\mathrm{Pi}$ :Jumlah plot yang ditemukan jenis $\mathrm{i}$

$\Sigma \mathrm{P}:$ Jumlah semua plot

\section{Frekuensi Relatif (\%)}

Untuk mengetahui frekuensi relatif jenis plankton dianalisis dengan menggunakan formula Bengen (2000):

$\mathrm{Rfi}=\mathrm{Fi} / \Sigma \mathrm{F} \times 100$

Dimana :

$$
\begin{array}{ll}
\mathrm{RFi} & =\text { Frekuensi relatif } \\
\mathrm{Fi} & =\text { Frekuensi jenis } \mathrm{i} \\
\mathrm{LF} & =\text { Frekuensi semua jenis }
\end{array}
$$

\section{Indeks Nilai Penting (INP)}

Indeks Nilai Penting jenis menurut Bengen (2000) :

$$
\text { INP }=R D i+R F i+R C i
$$

Dimana :

$$
\begin{array}{ll}
\mathrm{INP} & =\text { Nilai penting jenis } \\
\mathrm{RDi} & =\text { Kepadatan relatif jenis } \\
\mathrm{RFi} & =\text { Frekuensi relatif jenis } \\
\mathrm{RCi} & =\text { Dominansirelatif jenis } \mathrm{i}
\end{array}
$$

Nilai penting suatu jenis plankton berkisar antara 0 sampai 300 . Nilai penting ini akan memberikan suatu gambaran pengaruh atau peranan suatu jenis plankton dalam komunitas plankton (Bengen 2000).

\section{HASIL DAN PEMBAHASAN}

\section{Komposisi Jenis}

Hasil penelitian menunjukkan bahwa plankton yang ditemukan di perairan Pulau Bangka pada dua titik kedalaman terdiri dari 6 genera dari 5 ordo yaitu ordo Gonyaulacales 1 genus, ordo Bacillariales 1 genus, ordo Centrales 2 genus, dan ordo Oscillatoriales 1 genus.
Pada setiap stasiun pengamatan, diatom yang selalu di jumpai pada komunitas plankton di perairan Pulau Bangka adalah Skeletonema sp, Rhizosolenia sp, Coscinodiscus sp dan Chaetoceros sp. Sedangkan untuk dinoflagellata adalah Ceratium horridium. Hal yang sama juga ditemukan oleh Rimper (2001) di perairan Teluk Manado yang didominasi oleh diatom yaitu Chaetoceros sp, Bacteriastrum sp, Rhizosolenia sp, Coscinodiscus sp, Thalassionema sp dan Thalassiothrix sp, sedangkan untuk kelompok dinoflagellata yaitu Ceratium sp, Dinophysis sp, Pyrocystis sp, Prorocentrum sp dan Noctiluca sp. Menurut Arniardi (1997) dalam Rimper (2001) untuk perairan pantai, diatom yang terpenting adalah dari Chaetoceros sp, Coscinodiscus sp dan Rhizosolenia sp. sedangkan dinoflagellata yang utama antara lain Ceratium sp, Dhynophysis sp dan Noctiluca sp.

Menurut Parsons et al. (1984) dalam Rimper (2001), diatom selalu terdapat pada semua perairan terutama pantai, sedangkan dinoflagellata dan Cyanophyceae selalu terdapat pada semua perairan tropis. Khusus untuk Chaetoceros sp. Genus ini selalu dijumpai pada daerah tropis dan daerah dingin (Friedrich 1969 dalam Rimper 2001).

Jenis plankton yang ditemukan pada setiap stasiun menunjukkan bahwa hampir semua daur hidupnya adalah holoplankton, plankton dari jenis diatom adalah yang banyak ditemukan. (Arinardi dkk, 1994 dalam Lombok 2003), mencatat bahwa banyaknya plankton di suatu perairan dapat digunakan sebagai petunjuk bahwa perairan ini merupakan tempat pemijahan dari biota tersebut.

\section{Kepadatan Plankton}

Jenis plankton yang selalu ditemukan pada setiap stasiun di lapisan permukaan air adalah Pseudoenotis doliolus, sedangkan jenis plankton yang selalu hadir di setiap stasiun di kedalaman 10 meter adalah Skeletonema sp dan Chaetoceros sp. Kepadatan 
tertinggi di lapisan permukaan air yaitu $6,400 \quad \mathrm{Ind} / \mathrm{m}^{2}$ (St. 5) sedangkan di kedalaman 10 meter yaitu 2,466 Ind/ $/ \mathrm{m}^{2}$ (St. 6) dan kepadatan terendah di lapisan permukaan air yaitu $0,466 \mathrm{Ind} / \mathrm{m}^{2}$ (St. 4) dan kepadatan terendah di kedalaman 10 meter terdapat di St. 3 yaitu $1,067 \mathrm{Ind} / \mathrm{m}^{2}$.

Kepadatan plankton yang terdapat di St. 5 (lapisan permukaan air) lebih tinggi dari pada stasiun-stasiun yang lain di kedua kedalaman lokasi penelitian, hal ini disebabkan jumlah spesies plankton yang hadir di St. 5 lebih banyak dibandingkan dengan stasiun-stasiun yang lain. Rendahnya kepadatan plankton di St.1 sampai dengan St. 4 di kedua kedalaman karena pada saat pengambilan sampel diduga terdapat arus dan gelombang yang kuat sehingga plankton di tiap stasiun tersebut rendah. Menurut Levasseur et al (1992) kekuatan pergerakan massa air akibat arus juga mempengaruhi kepadatan dan kelimpahan plankton, karena arus merupakan faktor fisik yang penting dalam distirbusi plankton, dimana arus akan membawa organisme menjauhi atau mendekati makanan, sedangkan untuk St.

6 rendahnya kepadatan di stasiun tersebut diduga karena rendahnya tingkat kecerahan di stasiun tersebut.

\section{Kepadatan Relatif}

Kepadatan relatif di lapisan permukaan air, spesies Pseudoenotis doliolus yang memiliki nilai kepadatan relatif tertinggi yaitu $26,897 \%$, sedangkan Trichodesmium sp memiliki presentase terendah yaitu $1,150 \%$.

Kepadatan relatif di kedalaman 10 meter, dimana presentase tertinggi disemua stasiun ialah Chaetoceros $\mathrm{sp}$ yaitu $31,310 \%$ sedangkan presentase terendah di semua stasiun berada pada Coscinodiscus sp dengan nilai presentase sebesar 2,500 \%.

Kepadatan relatif tertinggi di enam (6) stasiun yaitu Chaetoceros $\mathrm{sp}$ (diatom) kenyataan ini menunjukkan bahwa jenis ini mampu menyesuaikan diri dengan lingkungannya, perkembangbiakan dan pertumbuhan relatif cepat (Isnansetyo dan Kurniastuty 1995). Arinardi $d k k, 1994$ dalam Lombok 2003), mencatat bahwa banyaknya plankton di suatu perairan dapat digunakan sebagai petunjuk bahwa perairan ini merupakan tempat pemijahan dari biota tersebut.

\section{Indeks Dominasi}

Indeks Dominasi mendeskripsikan tentang jumlah keseluruhan plankton yang terdapat di setiap stasiun penelitian. Untuk di lapisan permukaan air kisaran indeks dominan adalah 0,230-0,592, sedangkan di kedalaman 10 meter 0,224 0,316 .

Indeks dominan untuk setiap stasiun menunjukkan suatu bentuk dominan jenis yang rendah. $\mathrm{Hal}$ ini didasarkan oleh Ludwig dan Reynolds (1988) yang menyatakan bahwa kisaran nilai dominan 0-0,50 menunjukkan bahwa daerah tersebut dominasinya rendah. Kisaran 0,50-0,75 menunjukkan bahwa daerah tersebut dominasinya sedang dan untuk nilai dominasi 0,75-1 menunjukkan keadaan suatu daerah dengan dominasi tinggi. Setiap stasiun memiliki dominasi rendah, karena kurangnya plankton yang dijumpai selama penelitian, sehingga mempengaruhi indeks dominansi spesies. Kenyataan ini menunjukkan bahwa di perairan Pulau Bangka tidak terdapat jenis plankton yang dominan.

\section{Indeks Dominan Relatif}

Nilai indeks dominan relatif di setiap stasiun di lapisan permukaan air, spesies Pseudoenotis doliolus memiliki nilai dominasi relatif tertinggi yaitu 36,041 , sedangkan yang terendah yaitu Trichodesmium $\mathrm{sp}$ dengan nilai dominasi relatif 0,120 . Dominasi relatif yang tertinggi di kedalaman 10 meter, yaitu Skeletonema $\mathrm{sp}$ dengan nilai dominasi 32,524 dan yang terendah yaitu Coscinodiscus sp dengan nilai 1,309. Skeletonema sp merupakan diatom yang bersifat eurythermal yang mampu tumbuh pada kisaran suhu $3-30^{\circ} \mathrm{C}$ dan juga bersifat hidup dilaut, pantai dan muara sungai (Isnansetyo dan Kurniastuti 1995) 


\section{Indeks keanekaragaman}

Nilai indeks keanekaragaman tiap stasiun di lapisan permukaan air stasiun (St.) 5, memiliki nilai keanekaragaman tertinggi yaitu $\mathrm{H}^{1}=1,557$, sedangkan yang terendah yaitu pada stasiun (St.) 4 , $\mathrm{H}^{1}=0,598$.

Nilai indeks keanekaragaman tiap stasiun di kedalaman $10 \mathrm{M}$, dimana stasiun (St.) 6 memiliki nilai keanekaragaman tertinggi yaitu $\mathrm{H}^{1}=$ 1,546 , sedangkan yang terendah berada pada stasiun (St.) 3 yaitu $\mathrm{H}^{1}=1,057$.

Keanekaragaman untuk setiap stasiun menunjukkan suatu bentuk keanekaragaman jenis yang sedang. Hal ini didasarkan atas (Odum 1994 dalam Lombok 2003) yang menyatakan bahwa kisaran nilai indeks keanekaragaman 0-1 menunjukkan bahwa daerah tersebut terdapat tekanan ekologis yang tinggi dan indeks keanekaragaman spesies rendah. Kisaran 1-3 menunjukkan indeks keanekaragaman yang sedang, untuk nilai keanekaragaman yang lebih besar dari 3 menunjukkan keadaan suatu daerah yang mengalami tekanan ekologi rendah dan indeks keanekaragaman spesiesnya tinggi. Keanekaragaman juga ditunjang oleh komunitas plankton itu sendiri dimana plankton akan berkumpul disuatu tempat yang disukai (Nontji 2008). Dari hasil analisis data dapat dikatakan bahwa keanekaragaman di perairan Pulau Bangka memiliki nilai keanekaragaman sedang, hal ini sesuai pernyataan bahwa suatu ekosistem dengan keanekaragaman tinggi atau sedang maka dominasinya rendah.

\section{Frekuensi Jenis}

Frekuensi jenis menunjukkan sebaran plankton yang ditemukan pada setiap stasiun di lokasi penelitian, frekuensi jenis yang tertinggi ditemukan di lapisan permukaan air, yaitu Pseudoenotis doliolus dengan frekuensi jenis yaitu 1 dan yang terendah yaitu Trichodesmium sp dengan frekuensi jenis 0,5 sedangkan frekuensi jenis yang terdapat di kedalaman 10 meter, frekuensi jenis yang tertinggi yaitu Skeletonema $\mathrm{sp}$ dan Chaetoceros $\mathrm{sp}$ dengan nilai frekuensi jenis 1 dan frekuensi jenis terendah yaitu Coscinodiscus sp dan Ceratium horridium dengan nilai frekuensi jenis 0,167. Hal yang sama ditemukan oleh Wiadnyana (1998) juga mendapatkan di pesisir Digul Irian jaya, bahwa kelompok diatom lebih padat dibandingkan dengan dinoflagelata. Menurut Nontji (2008) menyatakan bahwa kelompok diatom lebih padat dibandingkan dengan dinoflagelata dan kecepatan membelah sel diatom tergantung kepada kondisi lingkungan dan jenis diatomnya.

\section{Frekuensi Relatif}

Nilai indeks frekuensi relatif di setiap stasiun di lapisan permukaan air, spesies Pseudoenotis doliolus memiliki nilai frekuensi relatif tertinggi yaitu 23,0708 , sedangkan yang terendah yaitu Trichodesmium sp dengan nilai frekuensi relatif 11,5393. Frekuensi relatif yang tertinggi di kedalaman 10 meter yaitu Skeletonema sp dengan nilai 26,087 dan yang terendah yaitu Coscinodiscus sp dan Ceratium horridium dengan nilai 4,348. Dari kedua kedalaman frekuensi jenis yang tertinggi yaitu jenis Skeletonema sp. Menurut Arinardi dkk (1994) dalam Sunarto (2008), jenis diatom yang banyak dijumpai di perairan lepas pantai Indonesia antara lain Chaetoceros sp., Rhizosolenia sp., Thalassiothrix spdan Bachteriastrum sp, sedangkan pada daerah pantai atau muara sungai biasanya terdapat Skeletonema sp dan kadang-kadang Coscinodiscus sp. Sunarto (2008) menemukan beberapa jenis diatom yang terdapat di perairan pantai Teluk Hurun Lampung antara lain jenis Naviluca sp, Thalassiosithic sp, Rhizosolenia sp dan Skeletonema sp. Jenis Skeletonema sp kadang berlimpah, hal ini diduga karena jenis ini dapat memanfaatkan nutrien lebih cepat dari pada diatom lainnya.

\section{Indeks Nilai Penting (INP)}

Indeks nilai penting yang diperoleh berdasarkan hasil analisis pada lapisan permukaan adalah Pseudoenotis doliolus dengan nilai tertinggi yaitu 86,017 dan 
jenis Skeletonema sp, memiliki nilai penting tertinggi di kedalaman 10 meter dengan nilai 88,627 sedangkan yang terendah di lapisan permukaan yaitu Trichodesmium sp dengan nilai 12,809 dan dikedalaman 10 meter yaitu Coscinodiscus sp dengan nilai 8,157. Hasil analisis menunjukkan bahwa jenis diatom memiliki pengaruh dan peranan yang besar dalam suatu perairan. Diatom merupakan fitoplankton atau tumbuhan mikroskopis laut karena memiliki kemampuan fotosintesis yang tidak kalah dengan tumbuhan di darat (Nontji 2008).

\section{DAFTAR PUSTAKA}

BAKOSURTANAL. 1995. Peta Pulau Bangka dan Sekitarnya, Peta LPI 2417-06i.

Bengen, D.G. 2000. Sinopsis Ekosistem dan Sumber Daya Alam Pesisir. Pusat Kajian Sumberdaya Pesisir dan Lautan - Institut Pertanian Bogor. Bogor.

Cox, G.W. 1967. Laboratory manual of general ecology. W. M.c. Brown Company Publisher. USA. 165 hal.

Isnansetyo. A, dan Kurniastuty, 1995. Teknik Kultur Phytoplankton dan Zooplankton, Yogyakarta.

Levasseur, M., L. Fartier, J.C. Therriault and P.J. Harrison. 1992. Phytoplankton Dynamics in Coastal Jet Frontal Region. Marine Ecology Progress Series, 86:283-295.

Ludwig, J.A D and Reynolds, J.V. 1988. Statistical Ecology a Primer in Methods and Computing. John Wiley and Sons. New York.
Lombok, B.J.A. 2003. Struktur Komunitas Zooplankton di Teluk Manado dan Laut Flores. Skripsi Fakultas Perikanan dan Ilmu Kelautan Universitas Sam Ratulangi. Manado.

Nontji, A, 2008. Plankton Laut, Lembaga Ilmu Pengetahuan Indonesia. Jakarta.

Rimper, J.R.T.S.L, 2001. Kelimpahan dan Distribusi Fitoplankton di Perairan Teluk Manado Sulawesi Utara, Tesis. Program Pascasarjana Institut Pertanian. Bogor.

Romimohtarto, K. dan S, Juwana. 1999.

Biologi Laut. Puslitbang Oseanologi - LIPI:Jakarta.

Sunarto, 2008. Karya IImiah Karakteristik Biologi dan Peranan Plankton Bagi Ekosistem Laut. 